\title{
THE CORRELATIONSHIP BETWEEN SELF EFFICACY AND COMPLIANCE OF LOW SALT DIET IN THE ELDERLY WITH HYPERTENSION IN WORKING AREA OF JELBUK HEALTH CENTRE
}

\author{
Susi Wahyuning Asih 1), Maulida ZuhrotulJannah 2) \\ 1) Lecturer of Faculty Of Health Science, University of Muhammadiyah Jember \\ 2) Student of Bachelor Nursing Program, Faculty of Health Science, University of \\ Muhammadiyah Jember \\ Corresponding e-mail : susiwahyuningasih@ymail.com
}

\begin{abstract}
BACKGROUND : Self-efficacy is an individual's belief in his ability to organize and perform the specific tasks required to get results as expected. Compliance is the extent to which a person's behavior is committed to a therapeutic regimen that has been agreed with a health care provider. The purpose of this study was to determine the correlation of self efficacy with low salt diit adherence in elderly hypertension in Jelbuk District Jember Working Area.

SUBJECT AND METHODE : This research use correlation research design with cross sectional approach. The population in this study were 746 elderly with hypertension, with purposive sampling technique and proportional sampling with inclusion criteria and exclusion criteria were obtained as many as 149 .

RESULTS : The result of hypertension elderly with high self efficacy was $85.2 \%$, low self efficacy $14.8 \%$. Low salt with obedient $75.8 \%$, low salt diit adherence with non-adherence $24.2 \%$, self efficacy in good category and obdient in low-salt diit equal to $86,6 \%$, whereas self efficacy less with low salt diit compliance in adherence category $13,6 \%$ using Chi Square analysis obtained $p$ value 0.000 which means $\mathrm{H} 1$ accepted which means there is a relationship of self efficacy with low salt diit compliance.

CONCLUSION : In conclusion there is a relationship of self efficacy with adherence of low salt dit in elderly hypertension In Work Area Puskesmas Jelbuk Jember regency. It is expected that elderly increase self efficacy so that they coul run in low-salt diit.
\end{abstract}

Key words $\quad$ : Self Efficacy. Low-salt diit compliance. Hypertension

\section{INTRODUCTION}

As life expectancy increases, the nukber of elderly people in Indonesia tends to increase. The increasing number of elderly people will have an increasing impact, related to health and welfare problem of elderly. The goverment needs to formulate policies and programs aimed at the elderly so that they can play a role in development and not become the burden on the community (Ministry of Health, Republic of Indonesia, 2013).

Hypertension is a chronic disease that can damage organs. It is also called the silent killer becase it includes a deadly disease without any symptomsa first. One of the main problems in controlling hypertension is to increase compliance with hypertension diet (Puspita, 2012).

According to Roesma, the average salt consumption of Indonesian people is $15 \mathrm{grams} / \mathrm{day}$, while WHO recommendation is a maximum of 6 grams or 1 teaspoon a day. In the other hand, yhe culture 
of using cooking spice such as MSG has reached an alarming level. It is all causes hypertension in Indonesia increasing every year (Suara Karya, in Sarasaty, 2011).

Based on the data from the Jember District Health Office in 2016.Jelbuk Health Center is a health center with the highest prevalence of hypertension. There were 1799 people live with hypertension. The second place is Semboro health center with the number is 1511 people with hypertension and the third is Sabang Health center with 1114 people with hypertension. The elderly with hypertension in Jelbuk were counted as 746 elderly. Hypertension is one of big ten of morbidity in Jelbuk at 2016.

Feuer Stein et al (1998 in Tumenggung Imran, 2013) stated that there are several factors that affected compliance of diet program which is understanding of instruction, interaction quality, family social support and faith, attitide and personality. Form these four factors faith are believed to be one thing that strengthen patient's compliance. Self efficacy has been used to predict various helath behavior including the compliance in patients with chronic disease, and one of them is compliance of low salt diet in hyppertension. The aims of this study is to determine the correlationship between self efficacy and the compliance of low salt diet in elderly with hypertension.

\section{METHODE}

This is a correlation study conduct with cross sectional approach. This study involving 149 eldelry from total 746 elderly with hypertension in working area of Jelbuk health center. The respondents are taken by purposive sampling. The data collected by using general self efficacy questionnaire. Then the data analyzed by using Chi square test.

RESULT AND DISCUSSION

Table 1. Distribution Frequency of Respondents Gender in Working Area of Jelbuk Health Center (Primary Data, 2017)

\begin{tabular}{lll}
\hline Gender & Amount & Percentage (\%) \\
\hline Male & 74 & 49,7 \\
Female & 75 & 50,3 \\
\hline Total & 149 & 100 \\
\hline \multicolumn{2}{r}{ Based on the data in table 1 it can conclude that most respondents are female as much 75} \\
elderly (50.3\%).
\end{tabular}

Table 2. Distribution Frequency of Respondents Age in Working Area of Jelbuk Health Center (Primary Data, 2017)

\begin{tabular}{lll}
\hline Age (years old) & Amount & Percentage (\%) \\
\hline $45-59$ & 83 & 55,7 \\
$60-74$ & 66 & 44,3 \\
$75-90$ & 0 & 0 \\
$\geq 91$ & 0 & 0 \\
\hline Total & 149 & 100 \\
\hline \multicolumn{2}{r}{ According to the data on table 2 we can see that most respondents (55.7\%) are $45-59$} \\
years old.
\end{tabular}


Table 3. Distribution Frequency of Respondents Educational Degree in Working Area of Jelbuk Health Center (Primary Data, 2017)

\begin{tabular}{lll}
\hline Educational Degree & Amount & Percentage (\%) \\
\hline Elementary school & 111 & 74,5 \\
Junior high school & 25 & 16,8 \\
Senior high school & 13 & 8,7 \\
College & 0 & 0 \\
\hline Total & 149 & 100 \\
\hline \multicolumn{2}{c}{ Based on the data on table 3 we see that most respondents $(74.5 \%)$ were graduated from } \\
elementary school.
\end{tabular}

Table 4. Distribution Frequency of Respondents Self Efficacy in Working Area of Jelbuk Health Center (Primary Data, 2017)

\begin{tabular}{lll}
\hline Self Efficacy & Frequency & Percentage $(\%)$ \\
\hline High & 127 & 85,2 \\
Low & 22 & 14,8 \\
\hline Total & 149 & 100 \\
\hline
\end{tabular}

The data in table 4 shows that most respondents (85.2) has high self efficacy. Most of respondents in this study (85.2\%) shows that they has high self efficaction. It means that most elderly in working area of Jelbuk Health Center has high self effication.

The study that has been done by Sulistyaningsih (2017) stated that efficacy is form through the proccess of cognitive, motivation, affective and selection through lifetime. Theory of self efficacy are based on someone's hope related to spesific set of actions. It is a predictive theory about the confidence that someone could done certain behaviors.

Table 5. Distribution Frequency of Respondents Compliance on Low Salt Diet in Working Area of Jelbuk Health Center (Primary Data, 2017)

\begin{tabular}{lll}
\hline Compliance on Low Salt Diet & Frequency & Percentage (\%) \\
\hline Obey & 113 & 75,8 \\
Disobey & 36 & 24,2 \\
\hline Total & 149 & 100 \\
\hline
\end{tabular}

Based on the data in table 5 we see that majority of respondents $(75.8 \%)$ are obey to the rule of low salt diet. Self efficacy and family support play a big role in shaping someone's compliance. Self efficacy play a bigger role than family support. Eventhough someone has good family support but in the other side he has low self effication, it will make him become incompliance 
Table 6. Cross Tabulation of Self Efficacy and Compliance on Low Salt Diet in Elderly With Hypertension in Working Area of Jelbuk Health Center (2017)

The data in table 6 shows that from 127 respondents with high self efficacy has obey the the diet program as much as $86.6 \%$. Meanwhile from 22 respondents with low self efficacy, 3 respondents obey the diet program. It is confirmed by the results of statistical analysis using chi square test which show $p$ value $0.000<0.05$ so that hipothesis accepted. It means that there are significant correlationship between self efficacy and compliance on low salt diir in elderly with hypertension in working area of Jelbuk Health Center.

The data on table 5 show that most respondent $(75.8 \%)$ are obey the low salt diet. Barnet et al (2007) stated that the obedience to therapeutic regimen and avoiding or minimize the complication is an important factor that contribute to immunity and quality of life.

Obedience means how far someone behavior could maintain the commitment about the the therapeutic regiment agreed upon with the health advisor. The client and the advisor could affect the obedience sine when these two has good relationship then the client's obedience will improve so that the client will has better health behavior.

Meanwhile the disobedience will legthen the illness and healing proccess. Damayanti (2014) stated that self efficacy is the main predictor of behavior that affect the starting of some task, anny effort to finish the task, and time to accomplish the task. We believed that self efficacy have a correlationwith the compliance of low salt diet. Respondents are expected to enhance their self efficaction by predicting event and improve technicques to control any events that could effect their life and also motivate the self and do some guided anticipatory action to make sure the successful of the diet.

\section{CONCLUSION AND RECOMMENDATION}

From analytical statistic the correlationship of self effication and compliance of low salt diit show $p$ value 0,000 means that there are significat correlationship between self effication and compliance of low salt diit.

Recommendation

From the result above we recommend that the nurse as an educator need to educate the client about how to manage the hypertension so that they could manage the symptoms and enhance the obedience to the regiment thearapeutic.

\begin{tabular}{|c|c|c|c|c|c|c|c|c|}
\hline & \multicolumn{8}{|c|}{ Compliance on Low Salt Diet } \\
\hline & & Obey & & & & Total & & $P$ value \\
\hline \multirow{3}{*}{$\begin{array}{l}\text { Self } \\
\text { Efficacy }\end{array}$} & & $\mathrm{n}$ & $\%$ & $\mathrm{n}$ & $\%$ & $\mathrm{n}$ & $\%$ & \multirow{4}{*}{0.000} \\
\hline & High & 110 & 86.6 & 17 & 13.4 & 127 & 100 & \\
\hline & Low & 3 & 13.6 & 19 & 86.4 & 22 & 100 & \\
\hline Total & & 113 & 75.8 & 36 & 24.2 & 149 & 100 & \\
\hline
\end{tabular}




\section{REFERENCE}

Agrina,. Rini, S. S,. \& Hiritama, R. (2009). Kepatuhan Lansia Penderita Hipertensi Dalam Pemenuhan Diet Hepertensi.

Almarwah, I. M. (2016). Hubungan Spiritualitas Dengan Tekanan Darah Pada Lansia Penderita Hipertensi Di Wilayah Kerja Puskesmas Ambulu Kabupaten Jember Tahun 2016

Beck, E. (2011). IImu Gizi Dan Diet Hubungannya Dengan Penyakit-penyakit Perawat Dan Dokter.

Damayanti, S. (2014). HubunganAntaraSpiritualitas Dan EfikasiDiriDenganKepatuhanPasien Diabetes Mellitus Tipe 2 Di RS Jogja.

Hidayat,A.A. (2009). Metode Penelitian Keperawatan dan Teknik Analisis Data. Jakarta: Salemba Medika

Nainggolan, D. F. P., Armiyati, Y., \& Supriyono. (2012). Hubungan Dukungan Keluarga Dengan Kepathuan Diit Rendah Garam Dan Keteraturan Kontrol Tekanan Darah Pada Penderita Hipertensi Di Poliklinik RSUD Tugurejo Semarang.

Nisfiani, A, D. (2014). Hubungan Dukungan Keluarga Dengan Kepathuan Diit Hipertensi Pada Lanjut Usia Di Desa Begajah Kecamatan Sukoharjo Kabupaten Sukoharjo.

Notoatmojo, S.(2010). IImu Perilaku Kesehatan. Jakarta: Rineka Cipta.

Nugroho, Wahyudi. (2008). Keperawatan Gerontik \& Geritrik Edisi 3. Jakarta.

Puspita, A. (2012). Sikap Terhadap Kepatuhan Diit Hipertensi Dengan Tekanan Darah Pada Penderita Hipertensi Di Wilayah Kerja Puskesmas Doro II Kabupaten Pekalongan.

Sarasaty, R. F. (2011).Faktor-Faktor Yang Berhubungan Dengan Hipertensi Pada Kelompok Lanjut Usia Di Kelurahan Sawah Baru Kecamatan Ciputat, Kota Tangerang Selatan Tahun 2011

Tumenggung,. I. (2013). Hubungan Dukungan Keluarga Dengan Efikasi Diri Dengan Kepatuhan Diet Pasien Hipertensi Di RSUD Toto Kabila Kabupaten Bone Bolango 